Volume 1 Issue 2, September 2016: pp. 119-128. Copyright @ LamLaj. Faculty of Law, Lambung Mangkurat University, Banjarmasin, South Kalimantan, Indonesia. ISSN: 2502-3136 | e-ISSN: 2502-3128. Open Access at: http://lamlaj.unlam.ac.id

\title{
Penafsiran Pasal 40 Undang-Undang Nomor 10 Tahun 1998 Mengenai Kerahasiaan Bank
}

\author{
Ghina Rossana \\ Program Magister Kenotariatan Fakultas Hukum Universitas Lambung Mangkurat, Jalan \\ Brigjend H. Hasan Basri Banjarmasin, 70123 Indonesia \\ Telp/Fax: +62 5113307877 E-Mail: ghinarosana.123@gmail.com
}

Diterima: 19/7/2016; Revisi: 15/08/2016; Disetujui: 30/08/2016

\begin{abstract}
The aim of this research is to analyze the philosophical ground of Article 40 of Act Number 10 of 1998 concerning Banking which regulates the bank secrecy and to analyze the legal consequences which may occur in the event that debtor clients are not protected by the provision of Article 40 of Act Number 10 of 1998 concerning Banking. This is normative legal research by applying legislation approach, namely to study statutes related with the legal issues being studied, and conceptual approach by referring to the legal principle found in the legislation. The nature of this research is prescriptive analytical which is aimed to explaining accurately the characteristics of individuals, condition/ phenomena of particular groups in order to determine the spread of the phenomena in order to determine the existence or non-existence of the relation between one phenomenon and other phenomena in the society. The results of this research are firstly, the philosophical ground of Article 40 of Act Number 10 of 1998 concerning Banking is that the provision of the secrecy is aimed at increasing public trust to the banking world. Besides, the goals are also to protect the customers and public interest as well as to create healthy banking system. Secondly, the legal consequence as the debtor customers are not protected is that the saving and the financial condition of the customers are not abused by the banks in providing loans to the debtors..
\end{abstract}

Keywords: Article 40 of Act Number 10 of 1998, Bank Secrecy, Interpretation,

Abstrak: Tujuan penelitian ini adalah untuk menganalisis landasan filosofis Pasal 40 Undang-Undang Nomor 10 Tahun 1998 tentang Perubahan atas Undang-Undang Nomor 7 Tahun 1992 tentang Perbankan, yang mengatur kerahasiaan bank dan untuk menganalisa akibat hukum yang terjadi dalam hal tidak dilindunginya nasabah debitur dalam Pasal 40 Undang-Undang Nomor 10 Tahun 1998. Penelitian ini merupakan penelitian hukum normatif dengan menggunakan pendekatan perundang-undangan, yang dilakukan dengan cara 
menelaah semua undang-undang yang bersangkut paut dengan isu hukum yang ditangani dan pendekatan konseptual yang merujuk pada prinsip-prinsip hukum yang ditemukan dalam perundang-undangan. Sifat penelitian ini adalah preskriptif analisis yang bertujuan untuk menjelaskan secara tepat dari sifat-sifat suatu individu, kondisi/gejala keleompok tertentu/untuk menentukan penyebaran dari suatu gejala untuk menentukan ada dan tidaknya hubungan antara satu gejala dengan gejala lain di dalam masyarakat. Landasan filosofis Pasal 40 Undang-Undang Nomor 10 Tahun 1998 tersebut adalah ketentuan kerahasiaan yang dimaksud untuk lebih meningkatkan kepercayaan masyarakat terhadap dunia perbankan. Selain untuk melindungi nasabah juga untuk melindungi kepentingan masyarakat dan menciptakan sistem perbankan yang sehat. Akibat hukum tidak dilindunginya nasabah debitur dalam konteks kerahasiaan bank adalah memberikan jaminan bahwa simpanan dan keadaan keuangan nasabah tidak disalahgunakan oleh pihak bank dalam hal memberikan pinjaman kepada debitur.

Kata-kata kunci : Kerahasiaan Bank, dan Penafsiran

\section{PENDAHULUAN}

Bank sebagai lembaga keuangan yang eksistensinya tergantung mutlak pada kepercayaan dari para nasabahnya yang mempercayakan dana dan jasa-jasa lain yang dilakukan mereka melalui bank pada khususnya dan dari masyarakat pada umumnya. Oleh karena itu, bank sangat berkepentingan agar kadar kepercayaan masyarakat, yang sudah maupun yang akan menyimpan dananya, maupun yang telah atau akan menggunakan jasa-jasa bank lainnya terpelihara dengan baik dalam tingkat keamanan yang tinggi. Mengingat bank sebagai bagian dari sistem keuangan dan sistem pembayaran, masyarakat luas berkepentingan atas kesehatan dari sistem-sistem tersebut. Adapun kepercayaan masyarakat kepada bank merupakan unsur paling pokok. Sehingga terpeliharanya kepercayaan masyarakat kepada perbankan dapat berdampak positif pada kinerja dan perolehan laba dari bank tersebut.

Konsep rahasia bank bermula dari tujuan untuk melindungi nasabah yang bersangkutan.
Rahasia bank di Indonesia adalah salah satu penunjang kegiatan bank terutama dalam rangka menghimpun dana masyarakat. Dengan adanya ketentuan rahasia bank yang dalam hal ini mewajibkan bank dan pihak terafiliasi dengannya untuk merahasiakan keterangan nasabah penyimpanan dan simpanannya, tentunya sangat mendukung kepercayaan masyarakat dalam melakukan penyimpanan dananya di bank. Nasabah penyimpan sebagai pemilik dana akan merasa aman untuk menyimpan dananya di bank karena telah dilindungi oleh ketentuan rahasia bank. Kepercayaan yang baik dari pemilik dana kepada bank sangat diperlukan karena penyelenggaraan kegiatan penghimpunan dana masyarakat merupakan salah satu bidang usaha perbankan yang berperan sangat penting bagi kelangsungan usaha bank.

\section{METODE PENELITIAN}

Penelitian ini menggunakan jenis penelitian hukum normatif. Penelitian hukum normatif adalah penelitian hukum yang meletakkan hukum sebagai sebuah bangunan 
sistem norma. ${ }^{1}$ Peter Mahmud Marzuki menjelaskan bahwa penelitian hukum normatif adalah suatu proses untuk menemukan suatu aturan hukum, prinsip-prinsip hukum, maupun doktrin-doktrin hukum untuk menjawab permasalahan hukum yang dihadapi. Penelitian hukum normatif dilakukan untuk menghasilkan argumentasi, teori atau konsep baru sebagai preskripsi dalam menyelesaikan masalah yang sedang dihadapi. ${ }^{2}$

Tipe penelitian adalah doctrinal research, yaitu secara sistematisasi mengkoreksi dan memperjelas suatu aturan hukum yang berlaku pada bidang hukum tertentu, dengan cara melakukan analisis terhadap teks yang bersifat autoritatif yang meliputi bahan hukum primer dan sekunder. ${ }^{3}$ Dalam hal ini menganalisis ketentuan mengenai rahasia bank sebagaimana diatur dalam Pasal 40 Undang-Undang Nomor 10 Tahun 1998 tentang Perubahan atas Undang-Undang Nomor 7 Tahun 1992 tentang Perbankan (UU Perbankan), yang menyatakan bahwa nasabah penyimpan dan simpanannya yang wajib untuk dirahasiakan. Hal ini dipersempit dengan tidak lagi memuat nasabah debitur dalam hal ketentuan rahasia bank.

Pendekatan yang digunakan dalam penelitian ini adalah pendekatan perundangundangan (statute approach) dan pendekatan konseptual (conpetual approach). Pendekatan undang-undang adalah pendekatan yang dilakukan dengan menelaah semua undangundang dan regulasi yang bersangkut paut

1 Peter Mahmud Marzuki. (2005). Penelitian Hukum. Jakarta: Kencana, hlm. 35.

2 Ibid.

3 Dyah Ochtorina Susanti dan A'an Efendi. 2014. Penelitian Hukum (Legal Research). Jakarta: Sinar Grafika, hlm.15. dengan isu hukum yang diketengahkan. ${ }^{4}$ Dalam hal ini menganalisis UU yang mengatur masalah perbankan dan Peraturan Bank Indonesia (PBI) yang terkait dengan ketentuan rahasia bank. Sedangkan pendekatan konseptual dilakukan manakala peneliti tidak beranjak dari aturan hukum yang ada. Dalam menggunakan pendekatan konseptual peneliti merujuk prinsip-prinsip hukum yang dapat ditemukan dalam perundang-undangan para sarjana ataupun doktrin-doktrin hukum. ${ }^{5}$

\section{ANALISA DAN PEMBAHASAN}

\section{Landasan Filosofis Pasal 40 Undang- Undang Nomor 10 Tahun 1998 Yang Meng- atur Ketentuan Kerahasiaan Bank}

Dalam sistem perbankan Indonesia, mengenai rahasia bank selalu ditentukan dalam undang-undang yang mengatur tentang kelembagaan perbankan. Sesuai dengan perkembangan zaman dan kebutuhan masyarakat rumusan tentang rahasia bank itupun mengalami perubahan. Ketentuan rahasia bank mula-mula diatur dalam UndangUndang Nomor 7 Tahun 1992 tentang Perbankan (UU No. 7/1992) sebagai pengganti Undang-Undang Nomor 14 Tahun 1967 tentang Pokok-Pokok Perbankan (UU No. 14/1967). Sebelumnya rahasia bank diatur tersendiri dalam bentuk Peraturan Pemerintah Pengganti Undang-Undang (Perpu), yaitu Perpu Nomor 23 Tahun 1960 tentang Rahasia Bank (Perpu No. 23/1960) Terakhir konsep rahasia bank diperbaharui lagi dengan Undang-Undang Nomor 10 Tahun 1998 tentang Perubahan Atas Undang-Undang Nomor 7 Tahun 1992 tentang Perbankan (UU No. 10/1998).

\footnotetext{
4 Peter Mahmud Marzuki, Op. Cit, hlm. 93.

5 Ibid.
} 
Konsep rahasia bank sebelum UU No. 10/1998 sangat luas ruang lingkupnya. Rahasia bank seperti yang diatur dalam Perpu No. 23/1960, UU No. 14/1967 dan UU No. 7/1992, pada pokoknya berhubungan dengan penyimpanan dana maupun penerimaan kredit oleh nasabah, bahkan yang berkaitan juga dengan kegiatan dalam sistem pembayaran. Sementara pengertian dan ruang lingkup mengenai rahasia bank yang diatur diatur dalam UU No.7/1992 dan UU No. 10/1998 adalah berbeda. Melihat kondisi seperti itu maka sudah waktunya ada perubahan dan perbaikan total, yaitu kebijakan tidak boleh bersifat tambal sulam yang hanya bersifat menyelesaikan permasalahan secara temporer. Itikad tersebut perlu dilakukan perbaikan total dan harus ditindaklanjuti oleh DPR untuk mengganti UU No. 14/1967. Tujuan ini adalah penggantian dan penyempurnaan peraturan perbankan, yaitu dalam upaya mendukung kesinambungan dan peningkatan pembangunan, juga agar bisa mampu menampung perkembangan tuntutan jasa perbankan.

Pada UU No. 7/1992 ketidaknjelasan bersumber dari ruang lingkup rahasia bank yang terlalu luas, yaitu meliputi segala sesuatu yang berhubungan dengan keuangan nasabah dan hal-hal lain dari nasabah yang harus dirahasiakan menurut kelaziman dalam dunia perbankan. Kalimat "Segala sesuatu yang berhubungan dengan keuangan nasabah dan hal-hal lain dari nasabah", menunjukkan betapa luasnya ruang lingkup rahasia bank itu. Tolak ukur ruang lingkup mana yang harus dirahasiakan berkaitan dengan keadaan keuangan nasabah dan hal-hal lain dari nasabah ditentukan melalui kelaziman dalam dunia perbankan. Kelaziman ini dapat sangat bisa tergantung siapa yang menafsirkannya karena menurut teori hukum kelaziman itu masuk dalam katagori norma kabur (blanketnorm).

Jadi, UU 7/1992 menganut kerahasiaan bank yang luas, sebab yang dilindungi rahasia bank bukan saja keterangan dan keadaan keuangan nasabah debitur atau peminjamnnya. Ini berlainan dengan dengan UU No. 10/1998 yang membatasi atau mempersempit hal-hal yang wajib dirahasiakan oleh bank, yakni sebatas pada keterangan dan keadaan keuangan nasabah penyimpan dan bukan merupakan keterangan yang wajib dirahasiakan oleh bank. Di samping itu, Pasal 40 UU No. 10/1998 ini mengandung unsur subyektif berkaitan dengan hal yang harus dirahasiakan oleh bank, yaitu diri nasabah penyimpan dan unsur obyektif, yaitu simpanan nasabah. Dalam hal inilah yang wajib dirahasiakan. Namun masih dipertanyakan apakah dengan demikian berarti nama nasabah, alamat, nomor rekening, nomor mobil, hobi keluarga nasabah dan sebagainya masuk dalam kualifikasi yang harus dirahasiakan oleh bank. Siapakah yang dimaksud dengan nasabah penyimpan dana yang diri dan simpanannya harus dirahasiakan. Apakah seluruh nasabah penyimpan dana, baik perseorangan maupun badan hukum. Apakah hanya meliputi nasabah yang masih aktif atau juga meliputi mantan nasabah bank. Pasal 40 UU No. 10/1998 menetapkan bahwa bank wajib merahasiakan keterangan mengenai nasabah penyimpan dan simpanannya, kecuali dalam hal sebagaimana yang dimaksud dalam Pasal 41, Pasal 41A, Pasal 42, Pasal 43, Pasal 44 dan Pasal 44A. Ketentuan rahasia bank dimaksud berlaku pula bagi pihak terafilasi. Apabila nasabah bank adalah nasabah penyimpan dana yang sekaligus juga sebagai nasabah debitur, bank wajib tetap merahasiakan keterangan tentang nasabah dalam kedudukannya sebagai nasabah penyimpan dana. 
Apa yang dimaksud rahasia bank pada Pasal 1 angka 28 UU No. 10/1998 adalah segala sesuatu yang berhubungan dengan keterangan mengenai nasabah penyimpan dan simpanannya. Nasabah penyimpan adalah nasabah yang menempatkan dananya di bank dalam bentuk simpanan berdasarkan perjanjian bank dengan nasabah yang bersangkutan. Berdasarkan ketentuan diatas, maka kita bisa mengetahui kalau ruang lingkup rahasia bank dalam UU No. 10/1998 dipersempit atau dibatasi, yakni menyangkut:

1. Keterangan mengenai nasabah penyimpan dan simpanannya, artinya tidak termasuk keterangan mengenai nasabah debitur dan pinjamannya.

2. Kewajiban pihak bank dan pihak terafilasi untuk merahasiakan keterangan tersebut, kecuali dalam hal tidak dilarang oleh undang-undang

3. Situasi tertentu dalam mana informasi mengenai nasabah penyimpan dan simpananya boleh saja dibeberkan oleh pihak yang terkena larangan jika informasi tersebut tergolong pada informasi nasabah penyimpanan dan simpanannya yang termasuk dalam kualifikasi rahasia bank. Mengenai nasabah debitur dan pinjamannya yang tidak serta merta dapat menjadi keterangan yang terbuka dan dapat diberikan kepada siapapun juga, hal ini akan tergantung kepada syarat dan kondisi yang mengharuskan keterangan mengenai nasabah debitur dan pinjamannya menjadi terbuka dan kendatipun keterangan mengenai nasabah debitur dan pinjamannya tidak termasuk dalam ruang lingkup rahasia bank sebagaimana yang ditentukan dalam UU No. 10/1998. Nasabah debitur dan pinjamannya yang tidak serta merta dapat menjadi keterangan yang terbuka dan dapat diberikan kepada siapapun juga, hal ini akan tergantung kepada syarat dan kondisi yang mengharuskan keterangan mengenai nasabah debitur dan pinjamannya menjadi terbuka dan kendatipun keterangan mengenai nasabah debitur dan pinjamannya tidak termasuk dalam ruang lingkup rahasia bank sebagaimana yang ditentukan dalam UU No. 10/1998. Namun demikian kewajiban merahasiakan keterangan mengenai nasabah debitur dan pinjamannya tersebut telah beralih menjadi kewajiban secara perdata bank (termasuk pihak terafilasi) untuk merahasiakan mengenai nasabah debitur dan pinjamannya, yang timbul berdasarkan hubungan kontraktual antara bank dengan nasabah debitur yang bersangkutan. Dengan kata lain pengungkapan keterangan mengenai nasabah debitur dan pinjamannya harus pula didasarkan kepada syarat dan kondisi tertentu sesuai dengan yang telah diperjanjikan antara bank dengan nasabah debiturnya.

\section{Akibat Hukum yang Terjadi Dalam Hal Tidak Dilindunginya Nasabah Debitur Dalam Ketentuan Pasal 40 Undang-Undang Nomor 10 Tahun 1998 Tentang Kerahasiaan Bank}

Apabila diperhatikan secara seksama UU No. 10/1998, tidak ditemui ketentuan yang mengatur secara tegas perihal hubungan hukum antara bank dengan nasabah. Namun dari beberapa ketentuan dapat disimpulkan, bahwa hubungan hukum antara bank dengan nasabah diatur oleh suatu perjanjian. Hal ini dapat dilihat dari Pasal 1 Angka 5 UU No. 
10/1998, bahwa simpanan adalah dana yang dipercayakan oleh masyarakat kepada bank bank berdasarkan perjanjian penyimpan dan dalam bentuk giro, deposito, sertifikat deposito, tabungan, dan atau untuk lainnya yang dipersamakan dengan itu.

Landasan filosofis Pasal 40 UU No. 10/1998 yang mengatur mengenai kerahasiaan bank adalah bahwa dengan ketentuan kerahasiaan bank dimaksudkan untuk lebih meningkatkan tingkat kepercayaan masyarakat terhadap dunia perbankan, yang mana pada awalnya hanya untuk melindungi kepentingan nasabah semata-mata, namun kini juga bank yang bersangkutan dan sekaligus juga melindungi kepentingan masyarakat umum dalam rangka menciptakan sistem perbankan yang sehat dan transparan. Akibat hukum yang terjadi dalam hal tidak dilindunginya nasabah debitur dalam ketentuan Pasal 40 UU No. 10/1998 tentang kerahasiaan bank adalah akan berakibat pada dana masyarakat yang disimpan di bank. Karena kepercayaan masyarakat akan lahir terhadap bank apabila pihak bank memberikan jaminan bahwa simpanan dan keadaan keuangan nasabah tidak disalahgunakan oleh pihak bank dalam hal memberikan pinjaman kepada debitur. Diharapkan ada sebuah pengaturan yang melindungi nasabah debitur karena berjalannya sebuah kegiatan perbankan tidak terlepas juga dengan keberadaan nasabah debitur selaku pihak yang membutuhkan dana segar untuk menjalankan usahanya. Apalagi tidak semua nasabah debitur itu akan lalai dalam memenuhi prestasinya, bahkan adanya jaminan yang diberikan pihak debitur kepada bank, yang menjamin bahwa debitur beritikad baik dalam melakukan perjanjian kredit kepada pihak bank.

Dengan adanya bentuk perilndungan hukum yang jelas, yang berupa sebuah peraturan yang mengatur perilndungan hukum bagi nasabah debitur, maka diharapkan akan membuka peluang usaha lebih kondusif dan nyaman karena akan senantiasa mendapatkan jaminan perlindungan yang maksimal bagi nasabah debitur, sehingga kegiatan perbankan kita bisa berjalan dengan baik dan lancar. Dalam UU No. 10/1998, kategori nasabah dibedakan menjadi dua macam, yaitu: nasabah penyimpan dan nasabah debitur. Nasabah penyimpan adalah nasabah yang menempatkan dananya di bank dalam bentuk simpanan berdasarkan perjanjian bank dengan nasabah yang bersangkutan. Sedangkan nasabah debitur nasabah yang memperoleh fasilitas kredit atau pembiayaan berdasarkan prinsip syariah atau yang dipersamakan dalam hal dengan berdasarkan perjanjian bank dengan nasabah yang bersangkutan. ${ }^{6}$

Dalam UU Perbankan tidak ada ketentuan yang secara eksplisit yang mengatur hubungan hukum anatara bank dengan nasabah. Hubungan hukum antara bank dengan nasabah haruslah berdasarkan prinsip kepercayaan yang diikat dalam sebuah perjanjian atau kontrak. Selain itu salah satu hal penting dalam hubungan hukum antara bank dengan nasabah adalah perlunya bank untuk mengenal nasabahnya. Hal ini penting karena untuk menghindari jangan sampai terjadi yang disalahgunakannya untuk kepentingan pihak yang tidak bertanggungjawab. Salah satunya adalah jangan sampai terjadi kejahatan pencucian uang, baik yang secara langsung atau tidak langsung dilakukan oleh pelaku kejahatan. Dalam hubungan hukum antara

6 Rasjim Wiraatmadja. (1999). "Ketentuan Baru Rahasia Bank Menurut UU No. 10 Tahun 1998 serta Dampaknya Terhadap Perbankan dan kejahtan ekonomi." Jurnal Hukum Bisnis, Volume 8, hlm. 19-20. 
bank (kreditur) dengan nasabah peminjam dana (debitur), dimana hubungannya merupakan hubungan yang bersifat kepercayaan yang membebankan kewajiban-kewajiban kepercayaan (fiduciary obligation) kepada bank terhadap nasabahnya, maka masyarakat bisnis dan perbankan Indonesia telah melihat pula bahwa hubungan hukum antara bank dengan nasabah debitur adalah hubungan kepercayaan. Oleh karena itu bank hanya bersedia memberikan kredit kepada nasabah debitur atas kepercayaan bahwa nasabah debitur mampu dan mau membayar kembali kreditnya tersebut, maka juga hubungan antara bank dengan nasabah debitur adalah juga sebagai perjanjian kredit, bukan sekedar hubungan kontraktual biasa antara kreditur dan debitur atau antara bank dengan nasabah debitur, tetapi juga merupakan sebuah hubungan kepercayaan. Hal penting yang harus disadari oleh oleh para pihak (bank dan nasabah debitur) dalam perjanjian kredit khususnya bagi pihak debitur, bahwa implikasi yuridis yang muncul dalam hal dengan ditandatanganinya mengikat kedua belah pihak. ${ }^{7}$ Hubungan antara bank dengan nasabah mengacu pada hukum perjanjian. Hal ini berarti, para pihak dalam hal ini bank sebagai suatu badan usaha dan nasabah baik perseorangan maupun badan usaha, baik nasabah debitur maupun nasabah kreditur mempunyai hak dan kewajiban. Dalam hubungan antara bank sebagai penyalur dana (kreditur) dengan nasabah peminjam dana (debitur) juga memiliki hak-hak dan kewajiban yang harus ditaati oleh kedua belah pihak. Di mana kewajiban bank selaku kreditur adalah memberikan pinjaman sejumlah uang yang ditentukan dan memiliki hak untuk dibayar

7 Mariam Darus Badrulzaman. (1983). Perjanjian Kredit Bank. Bandung: Alumni, hlm 37. oleh nasabah debiturnya sejumlah yang telah ditentukan dalam perjanjian. Demikian pula dengan nasabah peminjam dana, memiliki hak untuk menerima sejumlah uang pinjaman dari pihak bank (kreditur) dan juga memilki kewajiban untuk memenuhi prestasinya tepat waktu. Setiap hak dan kewajiban yang harus dijalankan oleh berbagai pihak berbeda sesuai dengan layanan jasa apa yang digunakan oleh nasabah. Bisa saja kewajiban antara bank yang satu dengan bank yang lain hak dan kewajibannya berbeda-beda. Perjanjian kredit bank merupakan perjanjian timbal balik, artinya jika pihak dan nasabah debitur tidak memenuhi isi perjanjian, maka salah satu pihak dapat menuntut pihak lainnya sesuai dengan jenis prestasinya. Hubungan hukum antara bank dan nasabah peminjam dana (debitur) adalah perjanjian kredit bank yang mempunyai karakteristik tersendiri,

Dari peristiwa hukum yang terjadi antara bank melahirkan suatu hubungan hukum yaitu perjanjian kredit antara bank selaku pihak peminjam dana (kreditur) dengan nasabah peminjam dana (debitur). Dari hubunga hukum tersebut melahirkan akibat hukum yang terjadi antara bank dengan nasabah debitur. Dalam hal perjanjian kredit ini, akibat hukum yang dapat terjadi adalah dua kemungkinan, yaitu nasabah peminjam dana (debitur) telah melakukan prestasinya dengan baik, dengan melunasi hutangnya tepat waktu dan sesuai dengan apa yang diperjanjikan dan nasabah peminjam dana (debitur) lalai dalam memenuhi prestasinya (wanprestasi). Dalam sistem hukum perbankan Indonesia, pihak nasabah dibiarkan sendiri terlunta-lunta tanpa perlindungan yang predictable dan reasonable. ${ }^{8}$ Karena itu, salah satu masalah yang sering dikeluhkan adalah

8 Munir Fuady.( 2003). Hukum Perbankan Modern. Bandung: Citra Aditya Bakti, hlm. 99. 
tidak adanya atau kurangnya perlindungan terhadap nasabah jika berhubungan dengan bank nasabah debitur, nasabah deposan, maupun nasabah non-debitur nondeposan. Dalam beberapa kasus besar yang pernah terjadi di Indonesia, seperti kasus likuidasi Bank Summa (1984), Kasus Pidana di Bank Majapahit (1983), dan kasus likuidasi 16 bank bermasalah (akhir tahun 1997) menunjukkan bahwa kedudukan para nasabah masingmasing bank tersebut sangat krusial dan tidak terlindungi oleh hukum. Dalam kasus-kasus biasa lainnya sehari-hari, kedudukan nasabah bank bahkan lebih kritis berhubung tidak banyak mendapat sorotan dari masyarakat dan kurang mendapat tanggapan dari pihak otoritas moneter yang berwenang.

Adanya perlindungan hukum bagi nasabah selaku konsumen di bidang perbankan menjadi urgen, karena secara faktual kedudukan antara para pihak seringkali tidak seimbang. Di mana seharusnya perjanjian antara bank dengan nasabah seharusnya dibuat berdasarkan kesepakatan para pihak, karena alasan efisiensi maka diubah menjadi perjanjian yang sudah dibuat oleh pihak bank. Sedangkan nasabah sendiri tidak mempunyai pilihan lain, kecuali menerima atau menolak perjanjian yang telah disodorkan oleh pihak bank. Dengan adanya kerjasama yang baik antara bank dan nasabah, khususnya dalam hal mengenai kredit, maka diharapkan akan lebih akan mengoptimalkan perlindungan hukum bagi nasabah debitur sehingga dapat meminimalisir dispute yang berkepanjang dikemudian hari.

Dalam rangka memberikan perlindungan hukum bagi nasabah debitur, dalam UndangUndang Nomor 8 Tahun 1999 tentang Perlindungan Konsumen (UU No. 8.1999), bahwa selain ketentuan baku yang dalam UU No. 8/1999 dalam memberikan perlindungan hukum bagi nasabah dalam perjanjian kredit ini, maka perlu juga adanya perjanjian standart yang isinya tentang kerja sama yang baik antara bank dengan nasabah, maka diharapkan akan lebih mengoptimalkan perilndungan hukum bagi nasabah. Juga bentuk perlindungan yang dapat dilakukan untuk memberikan perlindungan kepada nasabah debitur adalah dalam pelaksanaan perjanjian kredit perbankan ditinjau dari UU No. 8/1999 terletak pada adanya kewajiban dari pihak bank untuk mengindahkan tata cara pembuatan klausula baku baik bentuk maupun substansinya dalam hal pembuatan perjanjian kredit untuk melindungi kepentingan-kepentingan nasabah debitur.

\section{PENUTUP}

Landasan filosofis Pasal 40 UU No. 10/1998 yang mengatur tentang kerahasiaan bank adalah ketentuan kerahasiaan bank dimaksudkan untuk lebih meningkatkan tingkat kepercayaan masyarakat terhadap dunia perbankan, yang mana pada awalnya hanya untuk melindungi kepentingan nasabah semata mata namun kini juga bank yang bersangkutan dan sekaligus juga melindungi kepentingan masyarakat umum dalam rangka menciptakan sistem perbankan yang sehat dan transparan.

Akibat hukum yang terjadi dalam hal tidak dilindunginya nasabah debitur dalam ketentuan Pasal 40 UU No. 10/1998 mengenai kerahasiaan bank adalah akan berakibat pada dana masyarakat yang disimpan di bank. Karena kepercayaan masyarakat akan lahir terhadap bank apabila pihak bank memberikan jaminan bahwa simpanan dan keadaan keuangan nasabah tidak disalahgunakan oleh pihak bank dalam hal memberikan pinjaman kepada debitur. 
Terhadap konsep rahasia bank yang diterapkan guna menjaga, melindungi dan memberikan jaminan bagi nasabah ketika menyerahkan keterangan pribadinya yang bersifat rahsaia kepada bank yang mempunyai hubungan kontraktual tersebut, sehingga diharapkan ke depannya perlu dibuat suatu ketentuan baku setingkat undang-undang mengenai rahasia bank sehingga dapat memberikan kepastian hukum tentang rahasia bank. Diharapkan ada sebuah pengaturan yang melindungi nasabah debitur, karena berjalannya sebuah kegiatan perbankan tidak terlepas juga dengan keberadaan nasabah debitur selaku pihak yang membutuhkan dana segar untuk menjalankan usahanya. Apalagi tidak semua nasabah debitur itu akan lalai dalam memenuhi prestasinya, bahkan adanya jaminan yang diberikan pihak debitur kepada bank, yang menjamin bahwa debitur beritikad baik dalam melakukan perjanjian kredit kepada pihak bank.

Dengan adanya bentuk perlindungan hukum yang jelas, yang berupa sebuah peraturan yang mengatur perlindungan hukum bagi nasabah debitur, maka diharapkan akan membuka peluang usaha lebih kondusif dan nyaman karena akan senantiasa mendapatkan jaminan perlindungan yang maksimal bagi nasabah debitur, sehingga kegiatan perbankan kita bisa berjalan dengan baik dan lancar.

\section{DAFTAR PUSTAKA}

\section{Buku-Buku}

Badrulzaman, Marius Darus. 1983. Perjanjian Kredit Bank. Bandung: Alumni.

Fajar, ND Mukti dan Yulianto Achmad. 2010. Dualisme Penelitian Hukum Normatif dan Empiris, Jakarta: Pustaka Pelajar.
Fuady, Munir. 2003. Hukum Perba-kan Modern. Bandung: Citra Aditya Bakti.

Marzuki, Peter Mahmud. 2005. Penelitian Hukum. Jakarta: Kencana.

Susanti, Dyah Octorina dan A'an Efendi. 2014. Penelitian Hukum (Legal Research). Jakarta: Sinar Grafika.

\section{Jurnal}

Rasyim, Wiraatmadja. 1999. "Ketentuan Baru Rahasia Menurut Undang-Undang Nomor 10 Tahun 1998 Serta Dampaknya Terhadap Perbankan dan Kejahatannya". Jurnal Hukum Bisnis, Volume 8.

\section{Peraturan Perundang-Undangan}

Kitab Undang-undang Hukum Perdata (Staatsblad Tahun 1847 Nomor 23, Diumumkan pada tanggal 30 April 1847).

Undang-Undang Nomor 14 Tahun 1967 tentang Pokok-Pokok Perbankan (Lembaran Negara Republik Indonesia Tahun 1967 Nomor 34, Tambahan Lembaran Negara Republik Indonesia Nomor 2842).

Undang-Undang Nomor 7 Tahun 1992 tentang Perbankan (Lembaran Negara Republik Indonesia Tahun 1992 Nomor 31, Tambahan Lembaran Negara Republik Indonesia 3473).

Undang-Undang nomor 10 Tahun 1998 tentang Perubahan Atas Undang-Undang Nomor 7 Tahun 1992 Perbankan (Lembaran Negara Republik Indonesia Tahun 1998 Nomor 182, Tambahan Lembaran Negara Republik Indonesia Nomor 3790).

Undang-Undang Nomor 6 Tahun 2009 tentang Bank Indonesia (Lembaran Negara Republik Indonesia Tahun 2009 Nomor 7, Tambahan Lembaran Negara Republik Indonesia Nomor 4962). 
Peraturan Bank Indonesia Nomor 2/19/ PBI/2000 tentang Persyaratan dan Tata Cara Pemberian Perintah atau Izin Tertulis Membuka Rahasia Bank (Tambahan Lembahan Negara Republik Indonesia Nomor 3998).

Peraturan Bank Indonesia Nomor 2/19/ PBI/2000 tentang Persyaratan dan Tata Cara Pemberian Perintah atau Izin Tertulis Membuka Rahasia Bank (Tambahan Lembahan Negara Republik Indonesia Nomor 3998).

Peraturan Bank Indonesia Nomor 7/6/PBI/2005 tentang Transparansi Informasi Produk Bank dan Penggunaan Data Pribadi Nasabah (Lembaran Negara Republik Indonesia Tahun 2005 Nomor 16 DP NP/ DPbs/DPB-PR).

Surat Edaran Bank Indonesia Nomor 7/25/ DPNP tanggal 18 Juli 2005 perihal
Transaparansi Informasi Produk Bank dan Penggunaan Data Pribadi Nasabah (Lembaran Negara Republik Indonesia Tahun 2005 Nomor 4475). 